\title{
Improving energy efficiency of school buildings during winter season using passive design strategies
}

\author{
Sahar Zahiri ${ }^{1, *}$ and Hasim Altan ${ }^{2, *}$ \\ ${ }^{1}$ Faculty of Technology, Design \& Environment, School of Architecture, Oxford Brookes University, Oxford, UK \\ ${ }^{2}$ Faculty of Architecture \& Fine Arts, Final International University, Kyrenia, 99370, Cyprus
}

Received: 2 January 2019 / Accepted: 20 October 2019

\begin{abstract}
Passive building design can improve energy efficiency of buildings, while providing comfortable indoor environment for occupants with minimum mechanical energy use. The foundation of passive design depends on natural sources of energy, which uses building architecture and surrounding environment to minimise heating and cooling loads of buildings with minimum operating and maintenance costs. The correlation of local climate with shape and thermal performance of buildings is one of the main considerations of passive design approach to reduce energy use and increase thermal comfort of occupants. This paper focuses on a series of field studies and building simulation analysis to improve thermal performance of female secondary school buildings in the city of Tehran in Iran during winter season using passive design strategies. The field studies included measuring indoor air temperature, as well as a questionnaire-based survey in a cold winter season in a typical female secondary school building. The on-site monitoring assessed indoor air temperature of classrooms while the occupants completed questionnaires covering their thermal sensations and thermal preferences. Moreover, building thermal simulation analysis were carried out using DesignBuilder tool to evaluate and improve thermal performance of classrooms based on students' thermal requirements and passive design strategies. The simulation analysis started from the basic school building model, investigating various passive design strategies to predict the optimum design strategies for the case study. The simulation results determined how to provide classrooms that are more comfortable for students with minimum energy use. The results of the field studies indicated that indoor thermal environment were usually comfortable for female students based on 7point ASHRAE scale. However, most of the occupants preferred their indoor thermal environment to be improved. Moreover, simulation results showed that building fabrics and thermal properties, as well as glazing and orientation had significant impacts on indoor air temperature and thermal comfort and using appropriate passive design strategies could improve energy efficiency of the building considerably. Therefore, in order to enhance indoor thermal environment and to increase learning performance of students, it is necessary to use appropriate low energy methods, which can reduce the needs for mechanical energy systems and hence save energy.
\end{abstract}

Keywords: Passive design / energy efficiency / thermal comfort / school buildings / DesignBuilder

\section{Introduction}

Passive design in buildings uses building architecture and surrounding environment to minimise energy use and improve thermal comfort of occupants, while reducing carbon emission production. According to Milker et al. [1], the correlation of local climate with shape and thermal performance of buildings is one of the main consideration of passive design approach to reduce energy use of building and increase thermal comfort of occupants. In general, the foundation of passive design depends on

\footnotetext{
* e-mail: hasimaltan@gmail.com; sahar.zahiri@gmail.com
}

natural sources of energy that reduce the needs for mechanical systems for cooling, heating and lighting in buildings $[2,3]$. Using surrounding environment is also one of the key factors in minimising the energy loads of buildings, while having low operating and maintenance costs $[4,5]$. Studies showed that passive design strategies in buildings could extend non-heating and non-cooling periods. It is also recommended to consider climatic design strategies at design stage [6] to increase the use of renewable energy system alongside passive design methods for creating low energy building [7]. The use of high efficiency mechanical energy systems and renewable energy technology beside the application of passive design can reduce energy use even further [8]. 
In addition, decreasing energy use should be a priority for all businesses and organisations as this helps to reduce energy costs, while tackling climate change. It should be noted that school sector uses considerable amount of energy in comparison to other sectors. However, simple and cost-effective solutions such as passive and environmental design can save energy and reduce costs. Students also spend considerable time in schools during academic years, which indicate the importance of the quality of indoor environment to increase their learning performance $[9,10]$. Appropriate passive design strategies such as solar control for warm climate and thermal insulation for cold regions can improve building performance and consequently reduce energy demands of schools, which usually use excessive energy to maintain indoor environment in an acceptable thermal condition $[10,11]$.

In order to create comfortable and healthy learning environments for students, one of the main subjects that needs to be considered during design process is thermal comfort. Based on Nicol and Humphrey [12], thermal comfort studies can help to frame sustainable design standards for buildings. Sustainable school buildings not only reduce energy consumption and buildings' running costs, but also increase thermal comfort of occupants and help to preserve non-renewable energy recourses [13]. Investigating thermal comfort in schools is very important because children are very sensitive to temperature variations, and considering their physical comfort is an important issue [14]. In order to enhance thermal comfort and to predict comfort boundaries, many studies have been conducted in different countries both for mechanically and naturally ventilated buildings. Heidari [15] conducted an extensive thermal comfort studies in Iran for more than fifteen years. Around 5000 sets of data were gathered during the 10 year of study in various climatic region of Iran for residential and office buildings. According to this study, indoor neutral temperature depends on outdoor temperature. Heidari [15] stated that Iranian people can achieve comfort at more than $30^{\circ} \mathrm{C}$ in a hot period and less than $20^{\circ} \mathrm{C}$ in a cool season. Moreover, it has been stated that, in a hot and dry climate of Iran, people can make themselves comfortable if they maintain indoor temperatures between $16.5^{\circ} \mathrm{C}$ and $22{ }^{\circ} \mathrm{C}$ in a cold season and between $28^{\circ} \mathrm{C}$ and $34^{\circ} \mathrm{C}$ in a hot season by adjusting their clothes, activity levels and air velocity.

Moreover, many studies and researches were conducted to provide high performance school buildings around the world. Many programmes also attempted to construct and refurbish school buildings based on sustainable and passive design strategies such as Building School for the Future in the UK. Building Schools for the Future (BSF) was a programme to rebuild or refurbish all secondary schools in England by 2020. It aimed at providing 21st-century facilities for all students in secondary schools and helping to study in more healthy and comfortable environments [16]. However, this scheme were scrapped [17] and many projects stopped. One of the main reasons was to get the best value for money [18]. Nevertheless, there were many useful guidelines and standards on school building designs in this programme that are extensive and can be changed to meet individual requirements for a particular design, while can offer good lessons for the future school building programmes.

In the country of Iran, the quality of school design has been improved in the recent years but most of existing schools have been constructed with the minimum concerns for thermal comfort of students and adaptation of buildings to local climate $[19,20]$. As mentioned earlier, the quality of indoor environment has a great influence on students' learning performance in classrooms [14] which confirms the importance of providing comfortable and healthy indoor environment for occupants. To develop environmental school design guidelines in Iran using passive design strategies, it is necessary to assess the current design methods used by the educational authorities in Iran and to examine the performance of existing schools which are one of the major energy consumers in non-domestic buildings [21,22]. According to an annual report of Central Bank of Iran [22], there were more than 112,500 schools in Iran including around 13,234 thousand students in 2011-2012. These statistics show how important it is to improve the quality of schools in the country to provide more comfortable and healthier indoor environment with minimum energy use. Although limited studies have been undertaken for school design in Iran, there is still lack of practical resources for environmental design of school buildings in Iran with concern to thermal comfort and energy efficiency $[19,23]$. It should be noted that a few guidelines are available for climatic school design in Iran but these guidelines need to be updated, while considering both genders' thermal satisfaction on indoor environment. The State Organisation of School Renovation, Development and Mobilization in Iran has proposed a climatic zoning for educational buildings and provided climatic design guidelines in various climatic regions in Iran [20]. Kasmai [24] also conducted a series of research studies on impacts of different climatic conditions on Iranian school designs. He reviewed available documents on thermal performance of school buildings, as well as climatic features, such as temperature and humidity, in order to divide educational buildings into different types in different regions and to present a climatic zoning map for school buildings. However, both studies have a lack of design guidelines for energy-efficient buildings based on students' thermal comfort.

This paper studies the effect of passive design strategies on energy efficiency and indoor thermal comfort in a female secondary school building in the city of Tehran, Iran during winter season. The aim of the study is to enhance thermal performance of school building and increase indoor thermal comfort of the occupants by using passive design strategies, and based on the female students' thermal satisfaction. In this study, a series of field studies were conducted, including thermal comfort surveys and field measurement of thermal comfort variables to predict the students' thermal satisfactions and indoor thermal condition. Thermal simulation analysis was also performed to evaluate and improve thermal performance and energy efficiency of the building using passive design strategies with respect to students' thermal comfort. 
Table 1. Materials, thickness and U-value of building components in case study school building.

\begin{tabular}{llll}
\hline Components & Materials & Thickness $(\mathrm{cm})$ & $U$-Value $\left(\mathrm{w} / \mathrm{m}^{2} \mathrm{~K}\right)$ \\
\hline Internal walls & Gypsum plastering & 2.5 & 1.831 \\
& Brick block & 10 & \\
External walls & Gypsum plastering & 2.5 & 1.614 \\
& Cement and render & 3 & \\
Internal floor & Brick block & 30 & 1.342 \\
& Gypsum plastering & 2.5 & \\
& Slate tiles & 2 & \\
Roof & Mortar & 2.5 & 0.527 \\
& Gight weight cast concrete \& Clay tile & 25 & \\
& Gypsum plastering & 1 & \\
& Asphalt & 2 & \\
& Mortar & 5 & \\
& Felt/Bitumen layers & 10 & \\
& Screed & 5 & 5.778 \\
\hline
\end{tabular}

It should be noted that Tehran has hot summers with low humidity levels and cold winters [24]. Annual precipitation is low and average rainfall on the plain is about $218 \mathrm{~mm}$. The average temperature during the hottest period is $29.6^{\circ} \mathrm{C}$ in July/August and during the coldest period is $3.1^{\circ} \mathrm{C}$ in January/February [25]. In general, the coldest period is in December, January and February and the hottest period is from June to August.

\section{Methodology}

In this paper, a series of field studies were conducted for one week in February, which represents the coldest period of the academic year. The field studies consisted of questionnaire-based survey and field monitoring of indoor thermal comfort variables including indoor air temperature. The indoor air temperature was measured using HOBO data loggers in two classrooms while the students completed questionnaires based on their thermal comfort perception and satisfaction [26]. The classrooms were located on the first (1st) and second (2nd) floors facing north (N) and south (S), respectively.

Moreover, the study evaluated thermal performance of the measured classrooms using building environmental analysis tool, DesignBuilder [27] during winter season. The data gathered from the field studies were also incorporated into building simulation model in order to validate the simulation tool by comparison of monitoring data with predicted data. After validating the software, indoor thermal condition of typical classrooms was assessed and later various passive design strategies were applied to the simulation model, including orientation, thermal mass, glazing and thermal insulation. This starts from the basic school building model, investigating various strategies to predict optimum conditions for the building based on female students' thermal requirements. The simulation results determined how to improve thermal performance and energy efficiency of school buildings for female students in Tehran and provide more comfortable indoor environment using passive design strategies.

\section{Case study building}

The case study is a typical female secondary school in the city of Tehran. The building has four storeys, including a basement and a ground floor with a masonry structure. The construction materials and thermal properties of the building are typical building materials used for masonry buildings such as brick as a thermal mass material and glass wool as a thermal insulation material (Tab. 1). It should be mentioned that $90 \%$ of the existing school buildings in Iran have a masonry structure $[28,29]$.

In this study, two classrooms were selected for field study experiment and simulation analysis, which represented all classrooms facing south (S) and all classrooms facing north $(\mathrm{N})$. The classrooms were located on 1st and 2nd floors (Fig. 1). These classrooms had the largest number of students, 23 and 21, close to national average number of students to classrooms in the country, which is 22 [22]. It should be mentioned that the school opening hours was from 7:30 am to 12:30 pm and the heating system of the building was a hot water radiator system, which was in operation $24 \mathrm{~h}$ a day during weekdays. However, the thermostat temperature was set to be low during night times as the school was unoccupied.

\section{Field measurement}

In this research, indoor air temperature was measured with HOBO data loggers in cold period of February 2011 for one 


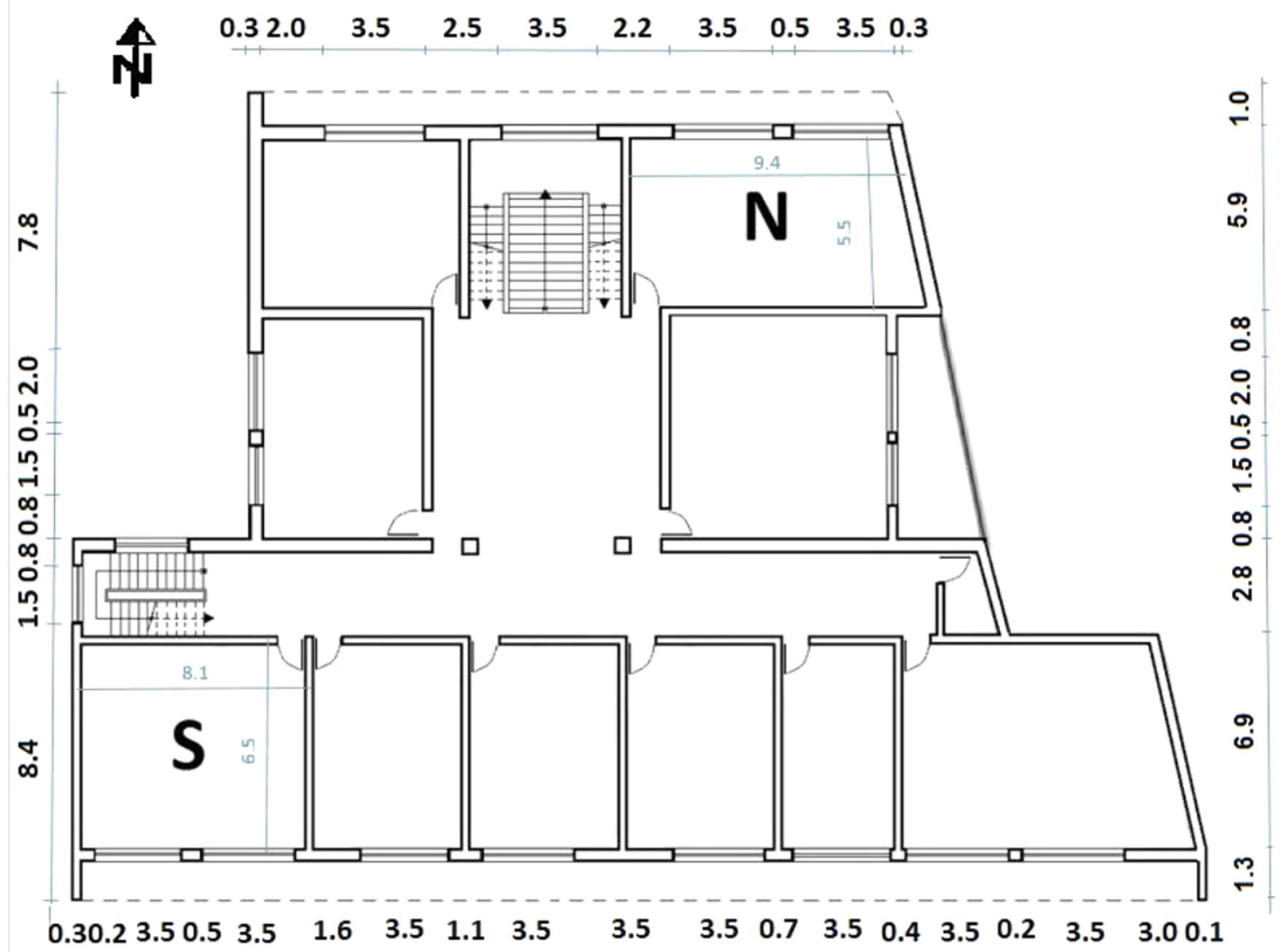

$\underline{1 \text { st and 2nd floors typical plan }}$

Fig. 1. Measured classrooms, S and N, on first and second floors.

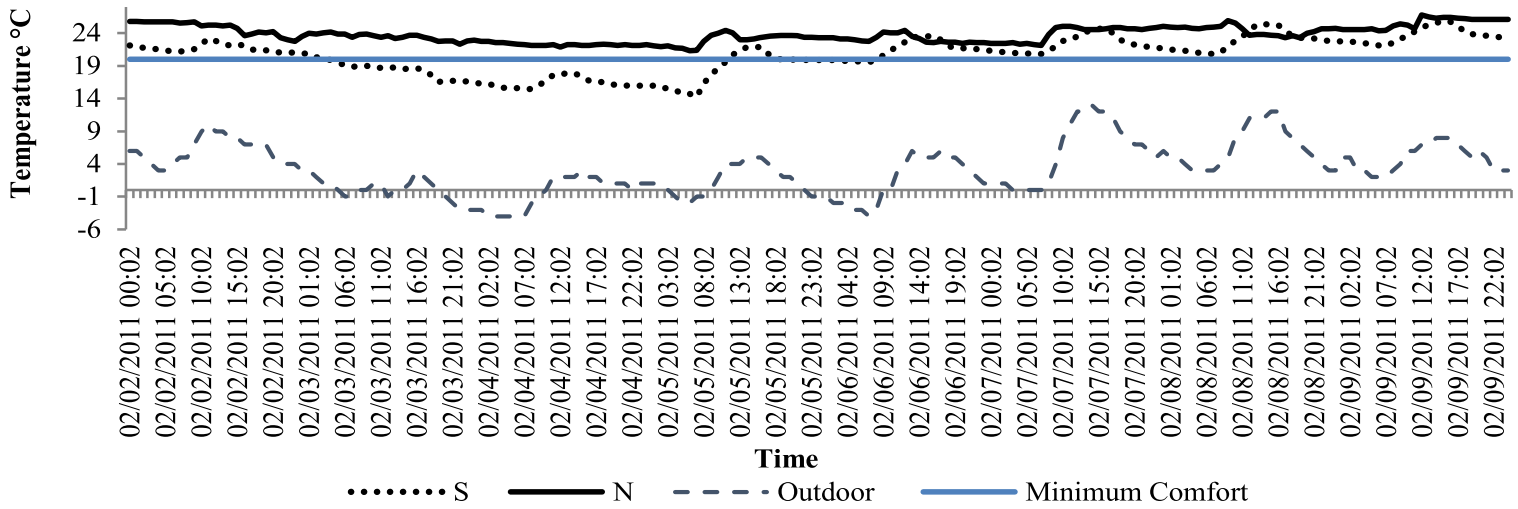

Fig. 2. Measured indoor air temperature in Classroom N and S for one week in February 2011.

week, which included a survey day. The measurements assessed thermal conditions of classrooms before the exam period and winter holiday (Fig. 2).

Based on field measurement results, the mean indoor air temperature was less than $21^{\circ} \mathrm{C}$ in Classroom $\mathrm{S}$ and around $23{ }^{\circ} \mathrm{C}$ in Classroom $\mathrm{N}$ during the February field study experiment, which slightly fell within Heidari's [15] defined comfort zone (Eq. (1)). Heidari's defined comfort zone was based on a decade of thermal comfort field studies on
Iranian people in residential and office buildings in fifteen cities and in four different climatic regions of the country [15]. It showed that the occupants were able to tolerate a wide range of temperatures, covering more than $14 \mathrm{~K}$ in a hot season and $7 \mathrm{~K}$ in a cool season. The findings showed that people could obtain comfort at colder indoor air temperatures in winter and higher indoor temperature in summer compared to previous international standards and recommendations. 
Table 2. The main questions regarding thermal comfort that were asked from the occupants during the survey.

\begin{tabular}{ll}
\hline Questions & Answers \\
\hline How do you feel at the moment? & Cold $\square$ Cool $\square$ Slightly cool $\square$ Neutral $\square$ Slightly warm $\square$ \\
& Warm $\square$ Hot $\square$ \\
Would you like to be & A bit cooler $\square$ No changes $\square$ A bit warmer $\square$ \\
What clothes are you wearing at the moment? & Please mention here \\
What activity did you do in the last 15 minutes? & Please mention here \\
What is your general impression of the classroom & Hot $\square$ just right $\square$ cold $\square$ \\
in terms of thermal comfort? & \\
\hline
\end{tabular}
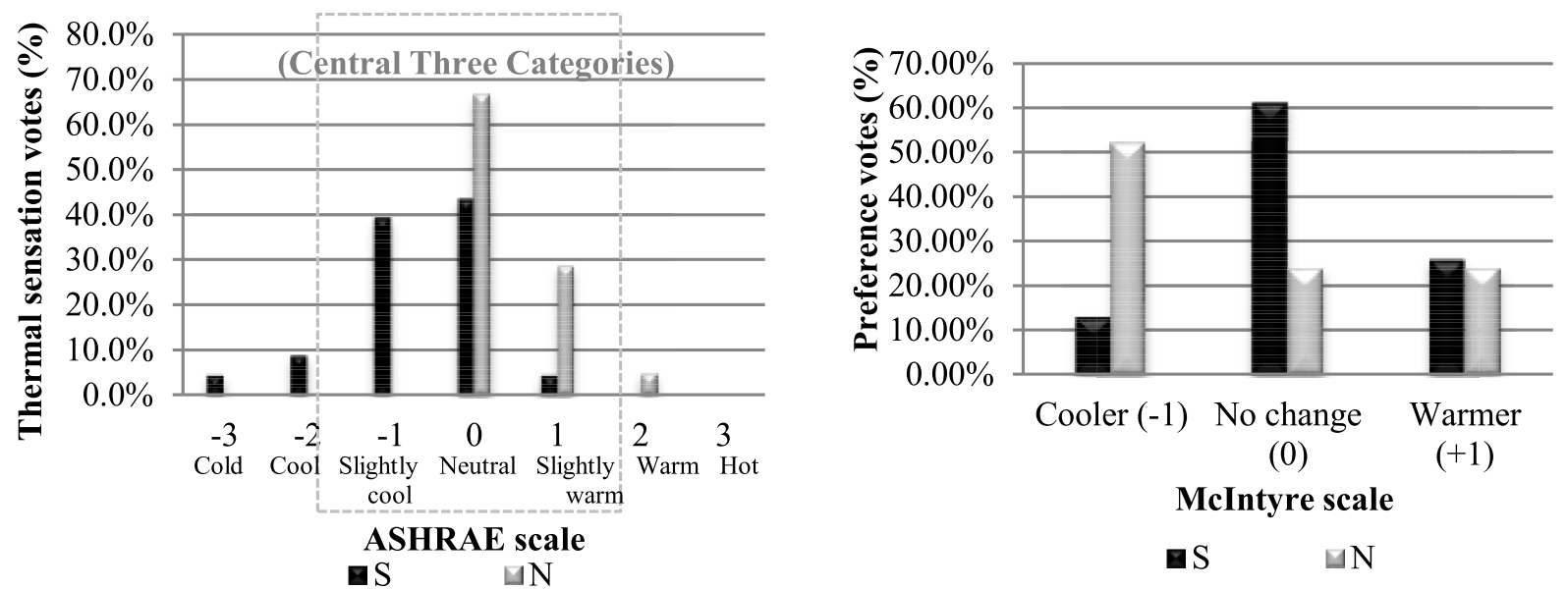

Fig. 3. Thermal sensation votes and preferences vote in classrooms $\mathrm{S}$ and $\mathrm{N}$ on 9 Feb 2011.

In order to identify the indoor comfort temperature $\left(T_{c}\right)$ in the case study school building and to predict initial comfort temperature ranges, the following equation (Eq. (1)) was used, which was based on Heidari's [15] predictions.

$$
T_{c}=17.80+0.30 T_{m o}
$$

$T_{m o}$ is the monthly mean outdoor temperature, $T c$ is the indoor comfort temperature.

Moreover, in this study, the mean radiant temperature was assumed to be equal to indoor air temperature in measured classrooms. According to Fanger [30] and Santamouris [31], when the occupants have sedentary activity less than 1.5 met and the air velocity is below $0.1 \mathrm{~m} / \mathrm{s}$, or the air is still in indoor environment, the mean radiant temperature can be assumed to be equal to indoor air temperature [30,31], which was the condition in the case study.

\section{Questionnaire survey}

The questionnaire-based survey was conducted in classrooms S and N, while indoor air temperature was measured with data loggers. The questionnaire survey was carried out on the $9 \mathrm{Feb} 2011$. Around 45 questionnaires were distributed in two classrooms and the students were asked to complete the questionnaires covering questions regarding their thermal sensations and thermal satisfaction using 7-point ASHRAE scale [32] and 3-point Mc-Intyre scale [33]. The main questions regarding the comfort of occupants that were included in the survey are presented in Table 2.

The results of the questionnaire survey indicated that the majority of students' responses fell into the central three categories of ASHRAE scale, slightly cool $(-1)$, neutral (0), and slightly warm $(+1)$ (see Fig. 3 ). Based on ASHRAE 55 standard [32], a response in central three categories of ASHRAE scale expresses satisfaction and more than $80 \%$ acceptability in three central categories is enough to consider indoor environment to be comfortable, which in this case was. In addition, around $60 \%$ of students in Classroom $\mathrm{S}$ wanted no change on their thermal environment and more than $50 \%$ in Classroom $\mathrm{N}$ preferred a cooler environment (Fig. 3). The average indoor air temperature during the teaching hours on the survey day was less than $21^{\circ} \mathrm{C}$ in Classroom S and was more than $25^{\circ} \mathrm{C}$ in Classroom N. Based on this study, most of the students in both classrooms felt neutral but the significant number 
of students preferred cooler environment when indoor air temperature was around $25^{\circ} \mathrm{C}$ and wanted no change when it was around $21^{\circ} \mathrm{C}$. It should be mentioned that the heating systems were always on during cold season and as a result most of the students in Classroom $\mathrm{N}$ wanted cooler environment although most of them felt within three central categories of the ASHRAE scale. The airtightness of Classroom S was also slightly low as the windows were not sealed enough, which caused air leakage and as a result the average indoor air temperature in Classroom $\mathrm{S}$ was less than Classroom N. Based on the outcomes of the survey in this research, the initial minimum comfort temperature in February was set to be $21^{\circ} \mathrm{C}$ as the significant number of students wanted no change and felt neutral at this temperature.

It should be noted that a big difference between indoor air temperature in classroom located in the south facing side $(\mathrm{S})$ and classroom located in the north facing side $(\mathrm{N})$ during winter season was the temperature of the thermostatic valves in the rooms. The results showed that although north facing side classroom received no solar radiation compared to south facing side classroom, the indoor temperature was higher. It was predicted that as Classroom $\mathrm{N}$ received no solar radiation, indoor air temperature was generally lower than Classroom S. However, to bring indoor air temperature to a comfortable condition, the occupants increased the thermostatic valves of radiators to the highest, while in Classroom $\mathrm{S}$ the temperature of thermostatic valves kept at a lower level as indoor air temperature was higher during the day time because of solar radiation, which caused the temperature difference in these two classrooms and as a result occupants felt less comfortable in Classroom $\mathrm{N}$ and preferred to be cooler.

\section{Simulation analysis}

In order to assess and improve indoor thermal performance of classrooms based on passive design strategies and students' thermal comfort satisfactions, thermal simulation analysis was performed using DesignBuilder buildings simulation tool. The simulation analysis was carried out on classrooms facing north $(\mathrm{N})$ and south $(\mathrm{S})$, located on the first and second floors of the building for one week in February 2011. The results of field studies were incorporated into the simulation model to evaluate the current thermal performance of school building. Later various passive design strategies were applied to the simulation model and the impacts of these strategies, including orientation, thermal mass, glazing and thermal insulation on indoor air temperature were separately analysed to identify an optimal solution for each strategy. Following this, the optimum design solutions were identified for the case study by combining all the optimal design solutions. It should be noted that the actual occupancy and heating energy use schedules were applied to the simulation model. Table 3 presents the proposed schedules for occupancy and heating system operation of the case study used in the simulation model based on the real-time schedules.
Table 3. Building operation schedules of the base case building model.

\begin{tabular}{ll}
\hline Building operation & Schedule \\
\hline Occupancy Period & $7: 30$ a.m. $-12: 30$ p.m. \\
Heating System & On \\
\hline
\end{tabular}

Regarding weather file applied in the simulation model, it was decided to use ITMY (Iran Typical Meteorological Year) file in EnergyPlus Weather format (EPW) provided by U.S. Department of Energy and derived from the Building and Housing Research Centre (BHRC) of Iran, which recorded a period of between 30 and 43 years [34]. A weather file is one of the main requirements that should be considered in building simulation analysis. Dynamic simulation and an hourly energy use calculation in some simulation programmes need hourly weather data for a complete year. As weather conditions change every year, various weather data files have been developed to be used for different simulation programmes based on the requirements [35].

In general, there are different types of weather data files, ranging from locally recorded weather data to a typical years weather data, which are used in various building simulation engines [36]. Different weather data sets have also been developed by various researchers. The most common formats of weather files are the Test Reference Year (TRY), Typical Meteorological Year (TMY, TMY2, TMY3) and International Weather for Energy Calculations (IWEC) [35]. Some of these formats are supported by EnergyPlus and DesignBuilder simulation tools, such as TMY and TRY formats [37]. TMY is based on an hourly report of the climatic data and has been developed after gathering weather data for several years [38]. TRY is based on the hourly observation of climatic variables, developed by hourly weather data sets [36]. DesignBuilder uses an EnergyPlus EPW format, which is derived from the Typical Meteorological Year 2 (TMY2) weather format [39].

In this study, to validate the accuracy of simulation analysis, indoor air temperature calculated by DesignBuilder were compared against field monitoring measurements during winter season by calculating the percentage of differences between field monitoring data and building simulation analysis, while applying actual weather variable data to the simulation model. The Percentage of Difference (PD) between DesignBuilder measurements, using actual weather data (AWD) and field measurements (FM) for indoor air temperatures were calculated by using below equation (Eq. (2)):

$$
\mathrm{PD}=((\mathrm{AWD}-\mathrm{FM}) / \mathrm{FM}) \times 100 .
$$

It was found that the average PD between simulation and monitoring results for indoor air temperatures in the measured classrooms was around $6 \%$, which is acceptable 

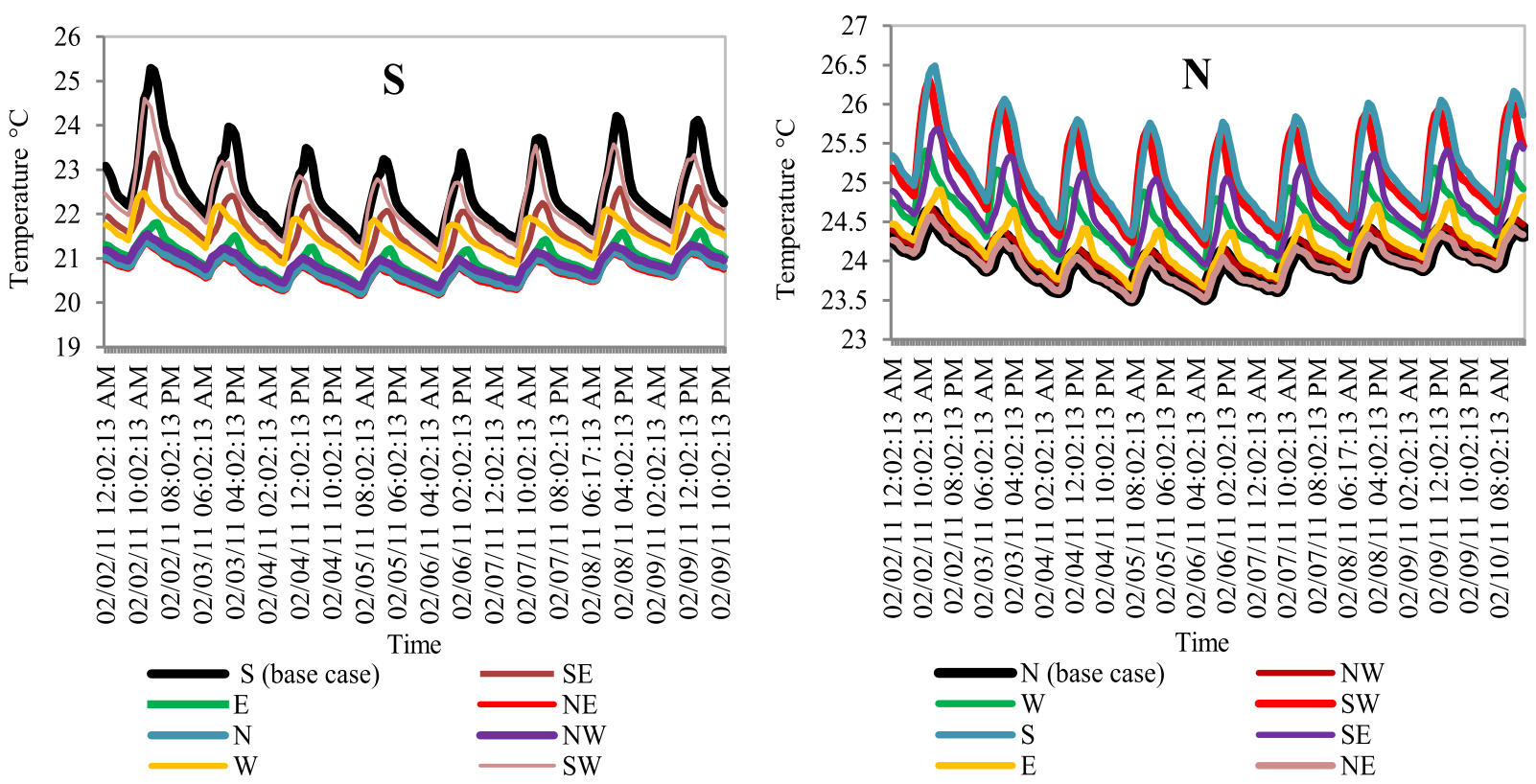

Fig. 4. Indoor air temperature profile using eight primary directions in classrooms S and N in February 2011.

and indicated that DesignBuilder is a satisfactory simulation tool that can be used for building environmental simulation analysis in this study.

\subsection{Orientation}

An appropriate building orientation can decrease the use of mechanical heating and cooling systems and, as a result, reduce the overall buildings' energy consumption. It is important to consider connection between geographical features of a site and buildings itself in order to create an accurate passive building [2]. Building orientation has an impact on heat gains of buildings, as a result of the variety of solar radiation at different angles [40]. To analyse the impact of orientation on indoor environment of the case study school building, a simulation analysis was performed considering various orientations. The eight main directions (N, NW, W, SW, S, SE, E and NE) were considered for the prototype school building, from $0^{\circ}$ to $315^{\circ}$. The building was rotated anti-clockwise for eight primary directions, starting with $0^{\circ}$ in the North. Figure 4 shows the variations of indoor air temperatures in classrooms $\mathrm{S}$ and $\mathrm{N}$, based on the eight main geographic directions. It can be seen that indoor air temperature was at the highest range when the south facade faced West and South-West, respectively, in Classroom S but when the facade faced North and NorthEast, the indoor air temperature dropped. However, indoor air temperature in Classroom $\mathrm{N}$ was increased in all directions. This was because the main facade of the classroom faced North in the base case and it received the minimum solar radiation, compared to the other directions.

Based on Kasmai [24], the southern walls gain direct solar radiation for $10 \mathrm{~h}$ a day in winter in the city of Tehran at $35^{\circ} \mathrm{N}$ latitude. However, the northern walls receive no solar radiation in winter season. The East and West walls also gain at least $4 \mathrm{~h}$ a day of sunshine in winter season. The comparison of indoor air temperature variations in all directions shows that the South and South West directions caused the maximum indoor air temperature in winter. However, when the classrooms faced North and North East, they had the minimum internal air temperature, compared to the other directions.

\subsection{Glazing}

Improving thermal efficiency of windows has a significant impact on heating demand of a building in a winter season as it becomes more airtight. To reduce heating demands of buildings, it is suggested to improve $\mathrm{U}$-value of a glazing area as much as possible [41]. Thermal characteristics of glazing area are an important part of window design, which has a considerable effect on thermal performance of indoor spaces. Thermal characteristics include U-values and insulation of windows, framing type and overall area of windows [1]. To improve thermal performance of glazing area, it has been suggested to increase the number of panes, up to triple glazing, which results in reducing U-value of windows [41].

In this study, the effect of windows on indoor air temperature was also investigated by applying various glazing types to windows, such as double glazed and triple glazed windows. Figure 5 shows the impact of various glazing types on indoor air temperature. The actual glazing type used in the case study was a $6 \mathrm{~mm}$ single glazed clear window. Two various double glazed windows were also selected for simulation analysis. The first double glazing type was a window with $3 \mathrm{~mm}$ and $6 \mathrm{~mm}$ panes with air as gas between the two panes. The second double glazing type 

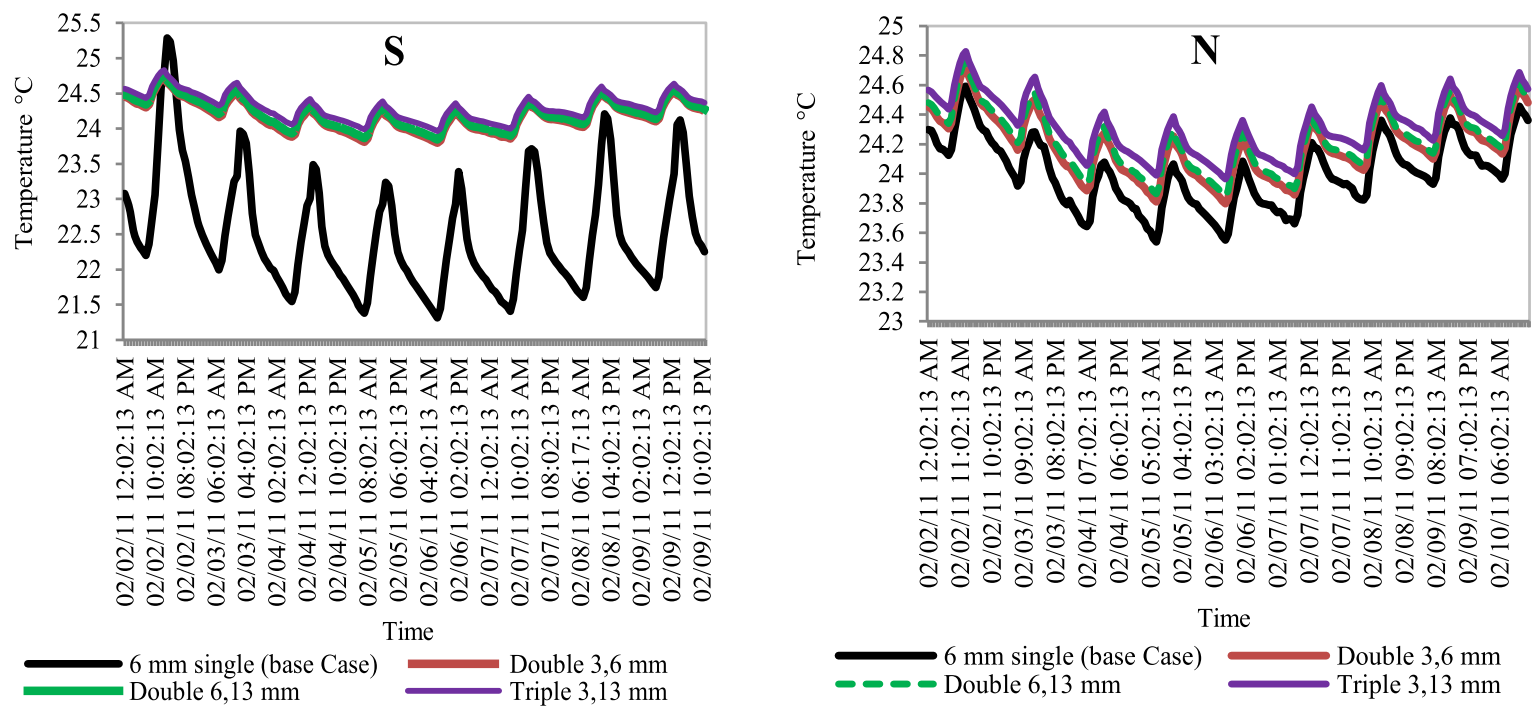

Fig. 5. Indoor air temperature profile using various glazing types in classrooms S and N in Jan/Feb 2011.

had $6 \mathrm{~mm}$ and $13 \mathrm{~mm}$ panes with air as gas between them. Another option was triple glazed windows with $3 \mathrm{~mm}$ and $13 \mathrm{~mm}$ panes with air between panes.

Indoor air temperature in both classrooms increased when double and triple glazed windows were applied to the simulation model but this increase was much more significant in Classroom S. As the difference between windows to external wall ratios in classrooms $\mathrm{S}$ and $\mathrm{N}$ was very minor, at around 0.06 and 0.05 respectively, a possible explanation for more temperature increase in Classroom $\mathrm{S}$ can be poor construction of this classroom. In general, it is suggested to use double glazed windows instead of triple glazed windows as the effect of both on indoor air temperature are nearly similar but double glazed windows are cheaper.

\subsection{Thermal insulation}

Thermal insulation materials have an impact on indoor air temperatures of buildings. A well-insulated building results in lower conductivity through building envelope fabrics, which decreases heat flow rate and as a result, can provide a comfortable indoor environment by minimum energy use $[2,42]$. The amount of heat loss from building components is usually measured by U-values or thermal transmittance. A lower U-value means lower heat loss thorough building fabrics and better insulation of buildings. In this study, different insulation types, with various thicknesses for external walls and roof were applied to the simulation model in order to examine their effects on indoor air temperature. The selected thermal insulation materials were based on Iranian national building regulation recommendations, which are the most typical insulation materials used in the country [43-45].

\subsubsection{Thermal insulation in external walls}

The original school building does not include any thermal insulation materials for external walls. Three various type of insulation materials were applied to external walls in the simulation model including glass wool, extruded polystyrene (XPS) and expanded polystyrene (EPS). They were applied to outer and inner sides of external walls separately with thicknesses of $5 \mathrm{~cm}$ and $10 \mathrm{~cm}$ to investigate the effect of positioning and thickness on indoor air temperatures. Figure 6 illustrates the result of simulation analysis using various insulation materials in Feb 2011. It can be seen that the application of all types of selected thermal insulation with $5 \mathrm{~cm}$ and $10 \mathrm{~cm}$ thicknesses resulted in higher indoor air temperatures in both classrooms. The application of thermal insulation materials reduced heat transfer from external walls and as a result provided higher indoor air temperature because of lower U-value compared to the base case external walls that includes no thermal insulation materials.

Moreover, adding insulation material with $10 \mathrm{~cm}$ thickness resulted in a higher increase in indoor air temperature than thermal insulation with $5 \mathrm{~cm}$ thickness. Applying thermal insulation material on the outer side of the external walls had almost the same effect on indoor air temperatures as when it was located on the inner side of the wall. Based on the result of the simulation analysis, applying XPS insulation material with $10 \mathrm{~cm}$ thickness on the outer side of the external walls increased indoor air temperature to $25.3{ }^{\circ} \mathrm{C}$ and applying the same material to the inner side of the wall increased the indoor air temperature to $25.1^{\circ} \mathrm{C}$ at $12 \mathrm{pm}$. However, it is suggested to use thermal insulation material on the outer surfaces of external walls with mass construction to give the advantage of greater thermal mass in winter period. Thicker insulation material also results in lower U-values and as a result has more effect on increasing indoor air temperature. The U-value of external walls using thermal insulation materials with $10 \mathrm{~cm}$ thickness decreased from $1.61 \mathrm{~W} / \mathrm{m}^{2} \mathrm{~K}$ to $0.32,0.28$ and $0.32 \mathrm{~W} / \mathrm{m}^{2} \mathrm{~K}$ when using glass wool, extruded polystyrene (XPS) and expanded polystyrene (EPS) respectively (Tab. 4). In addition, XPS thermal insulation resulted in lower U-values compared to 

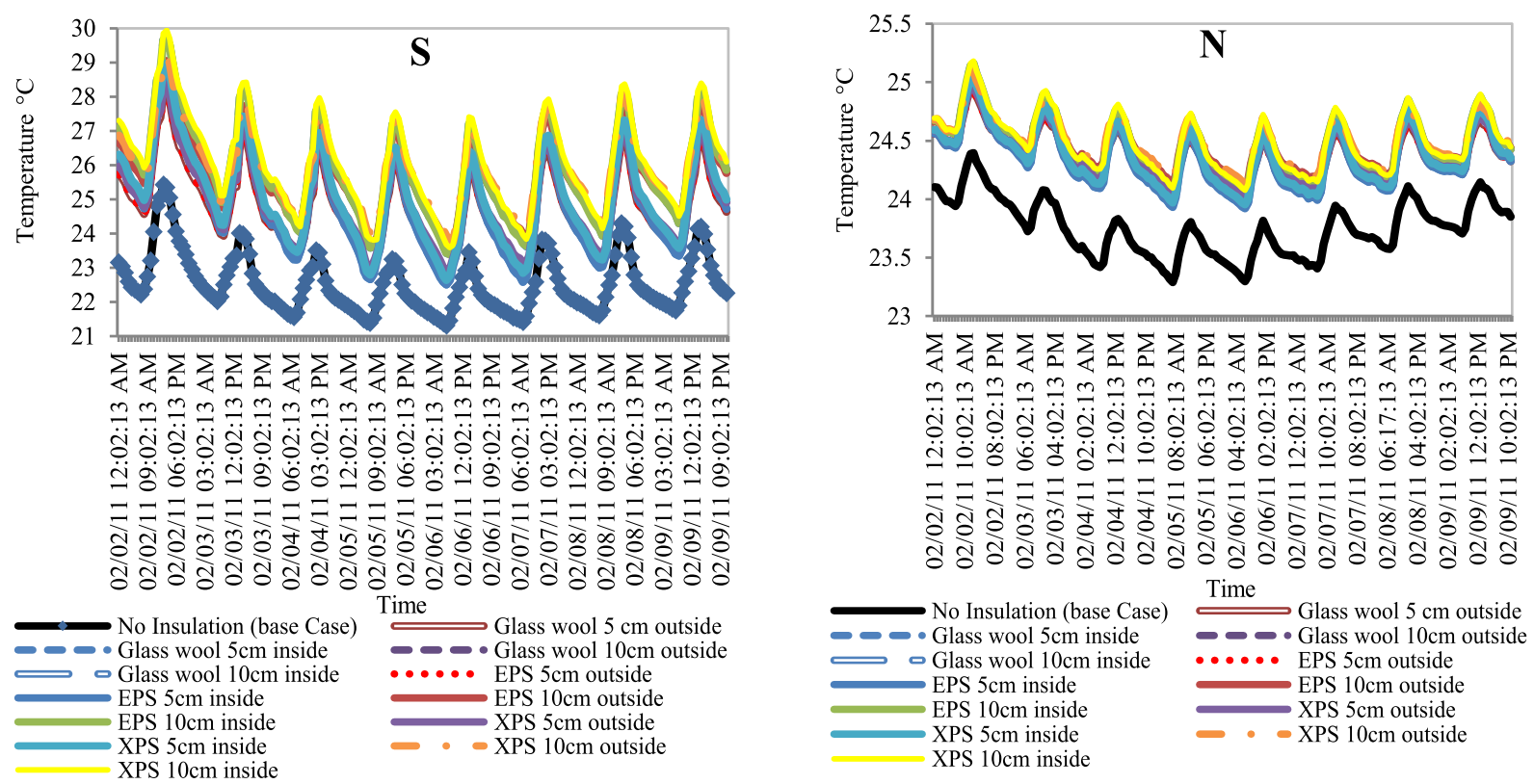

Fig. 6. Indoor air temperature profile using different wall insulation in classrooms S and N in Feb 2011.

Table 4. Effect of thickness of insulation materials on overall U-value of external wall.

\begin{tabular}{lll}
\hline Thermal Insulation & Thickness $(\mathrm{cm})$ & U-value $\left(\mathrm{w} / \mathrm{m}^{2} \mathrm{k}\right)$ \\
\hline Base Case & - & 1.614 \\
Glass wool & 5 & 0.535 \\
Glass wool & 10 & 0.321 \\
XPS & 5 & 0.478 \\
XPS & 10 & 0.281 \\
EPS & 5 & 0.535 \\
EPS & 10 & 0.321
\end{tabular}

other types of thermal insulation but the difference was very minimal.

\subsubsection{Thermal insulation in roof}

The base case building has already had $5 \mathrm{~cm}$ of glass wool installed in roof layer as a thermal insulation material. At the simulation phase in this study, three typical types of insulation materials were applied to the roof layers in a similar way to external wall experiment explained in Section 6.3.1. The applied insulation materials included glass wool, XPS and EPS. They were applied to the outer and inner sides of roof separately, with $10 \mathrm{~cm}$ thickness to investigate the impact of positioning and thickness of the insulation materials on indoor air temperature. Figure 7 presents the effects of various thermal insulation materials on indoor air temperature. The insulation materials were only applied to the outer side and inner side of the north-facing classroom's roof as the southfacing classroom located on the first floor, while north facing classroom located on top floor. It can be seen that
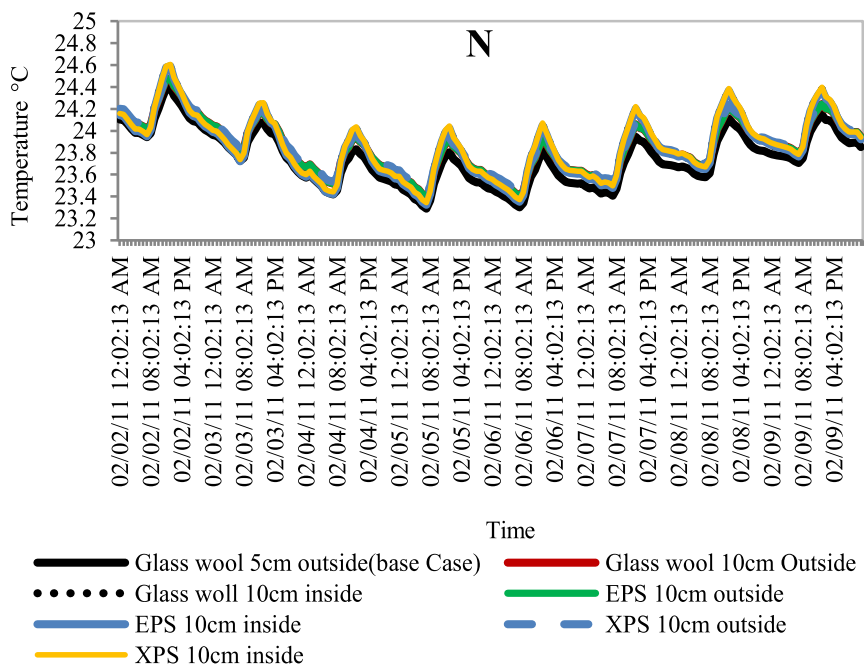

Fig. 7. Indoor air temperature profile using different roof insulation materials in classrooms $\mathrm{N}$ in May 2010.

the application of all types of thermal insulations with $10 \mathrm{~cm}$ thickness caused slightly higher indoor air temperatures in Feb 2011. The indoor air temperatures only increased by around $0.3{ }^{\circ} \mathrm{C}$ in this classroom, which shows that $5 \mathrm{~cm}$ thickness for thermal insulation is enough to keep indoor air temperature in an acceptable comfort range.

Table 5 presents the U-values of roof using different thermal insulation. The applied thermal insulation materials included glass wool, XPS and EPS that improved the U-vale of the base case and reduced it from $0.53 \mathrm{~W} / \mathrm{m}^{2} \mathrm{~K}$ to $0.32,0.28$ and $0.32 \mathrm{~W} / \mathrm{m}^{2} \mathrm{~K}$ respectively. As can be seen, the application of XPS with $10 \mathrm{~cm}$ thickness improved the U-value of the roof more than other types of thermal insulations. 
Table 5. Effect of thermal insulation materials and their thicknesses on U-value of the roof.

\begin{tabular}{lll}
\hline Insulation & Thickness $(\mathrm{cm})$ & $\mathrm{U}$-value $\left(\mathrm{W} / \mathrm{m}^{2} \mathrm{~K}\right)$ \\
\hline Base Case & 5 & 0.527 \\
Glass Wool & 10 & 0.318 \\
XPS & 10 & 0.279 \\
EPS & 10 & 0.318 \\
\hline
\end{tabular}
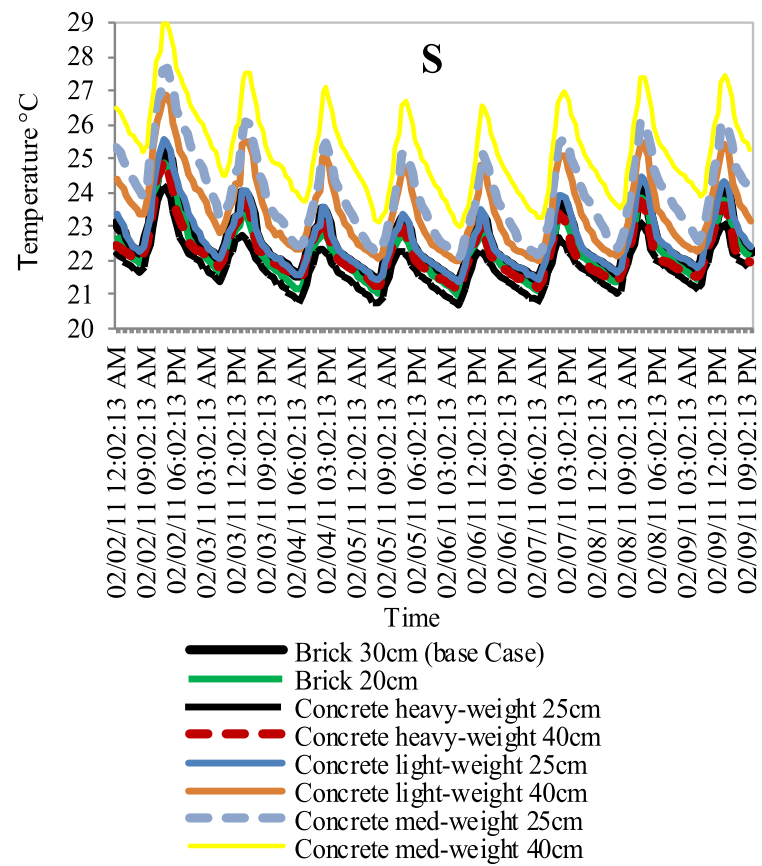

Table 6. Thermal mass materials using different thicknesses in external wall components.

\begin{tabular}{ll}
\hline Thermal Mass & Thickness $(\mathrm{cm})$ \\
\hline Brick (base case) & 30 \\
Brick & 20 \\
Heavy concrete & 25 \\
Heavy concrete & 40 \\
Medium concrete & 25 \\
Medium concrete & 40 \\
Light concrete & 25 \\
Light concrete & 40 \\
\hline
\end{tabular}

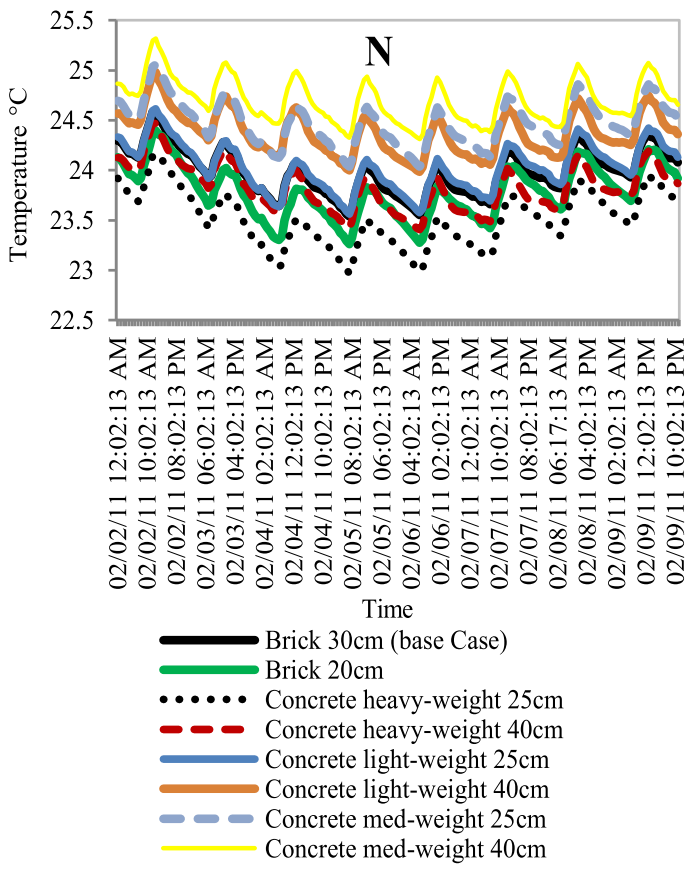

Fig. 8. Indoor air temperature profile using different thermal mass materials in classrooms $\mathrm{S}$ and $\mathrm{N}$ in Jan/Feb 2011.

\subsection{Thermal mass in walls}

Thermal mass is the capability of fabrics to save heat. It can be integrated into a building as part of buildings components in walls and floor. High thermal mass materials, such as concrete, brick, stone and earth, can absorb and hold heat and release it slowly later when there is a temperature difference between materials and surroundings [2]. It is suggested to use high thermal mass materials in building components in hot regions, as this provides a comfortable indoor environment by reducing indoor air temperatures and avoiding overheating in summer [24]. Based on Kruger and Givoni [46], using high thermal mass materials in external walls keeps indoor air temperatures in an acceptable condition in winter period as these material absorb heat of surroundings during day time and release it slowly at night [46]. In this study, various thermal mass materials with different thicknesses were applied to simulation model (Tab. 6).
Figure 8 shows indoor air temperatures variations in Classrooms $\mathrm{N}$ and $\mathrm{S}$ using different thermal mass material in building components. It can be seen that the application of thicker heavyweight thermal mass resulted in lower reduction in indoor air temperatures in both classrooms. Based on literatures, the impact of thermal mass can be increased by increasing thermal density and decreasing thickness of the material, which provides more constant heat capacity. A thinner mass material responds faster to surface temperature fluctuations and consequently stores excess heat gains and improve interior air temperatures more effectively [6,47-49]. It is also essential to locate thermal mass in a position where it can receive direct solar radiation to have more impact on improving indoor air temperatures $[13,47]$.

In addition, it can be seen that using lightweight and med-weight concrete increased the indoor air temperatures in both classrooms. Based on Ries and Holm [50], using lightweight concrete in buildings' envelope causes longer 
time lags. Vangeem et al. [51] also reported that reducing density of concrete masonry walls results in increasing thermal lag. They cited that for external uninsulated concrete walls, the beneficial effects of thermal mass are increased as density is reduced from $2400 \mathrm{~kg} / \mathrm{m}^{3}$ to $800 \mathrm{~kg} /$ $\mathrm{m}^{3}$, which might be a possible reason for having higher temperatures when using lightweight concrete masonry walls compared to heavyweight concrete. However, in this study, it is suggested to use heavyweight thermal mass material with thicker thickness in order to reduce indoor air temperature in warm season to avoid overheating in summer.

\section{Final discussion and conclusion}

In this study, building performance of a female secondary school building in the city of Tehran was evaluated and improved using building environmental simulation tool and by the application of passive design strategies to the simulation model. The study included field study and building simulation analysis. The field study consisted of indoor monitoring of climatic variables (e.g. indoor air temperature) and questionnaire-based survey on thermal comfort of the occupants. To validate the building simulation model, the results of field measurement were compared to the predicted results by applying actual weather data obtained from the field measurement and local weather station to the simulation model. The results showed that the percentage of difference between the actual measurement and the predicted result was around $6 \%$ that showed DesignBuilder simulation tool was an acceptable software to be used for simulation analysis in this study.

After validating the software, different passive design strategies were applied to the simulation model to predict the optimum design solutions for the case study building based on the occupants' thermal comfort that found to be between $20^{\circ} \mathrm{C}$ and $24.5^{\circ} \mathrm{C}$ using the minimum heating energy use. It should be noted that the questionnaire-based survey indicated that indoor environment were considered comfortable based on the 7-point ASHRAE scale as more than $80 \%$ of votes were within three central categories of ASHRAE scale (slightly cold, neutral, slightly warm), while heating system was in operation. However, the occupants preferred their indoor environment to be improved in cold seasons to increase their learning productivity in classrooms.

Moreover, the optimum factors were taken from the impact of selected passive design strategies, including orientation, glazing, thermal mass and thermal insulation, on indoor thermal comfort that was improved considerably with minimum energy use and with respect to female students' thermal satisfaction. The study showed that double glazed and triple glazed windows and outer thermal insulation for external walls with U-value between $0.28 \mathrm{w} /$ $\mathrm{m}^{2} \mathrm{k}$ and $0.32 \mathrm{w} / \mathrm{m}^{2} \mathrm{k}$, as well as heavyweight thermal mass materials with $25 \mathrm{~cm}$ thickness could improve building performance considerably, while keeping indoor air temperature within thermal comfort zone. In overall, triple glazed windows could improve indoor thermal environment slightly more than double glazed windows but as double glazed windows are cheaper than triple glazed windows, it is suggested to use double glazing, which can keep indoor air temperature between nearly $24^{\circ} \mathrm{C}$ to just above $24.5^{\circ} \mathrm{C}$ in south facing and north facing side classrooms.

In terms of thermal properties of external walls, thicker thermal insulation with $10 \mathrm{~cm}$ thickness in outer side of the walls could improve indoor thermal comfort more than using thermal insulation with $5 \mathrm{~cm}$ thickness, which could keep indoor air temperature between $23.5^{\circ} \mathrm{C}$ and just below $29^{\circ} \mathrm{C}$ in Classroom S and between around $24^{\circ} \mathrm{C}$ and just below $25^{\circ} \mathrm{C}$ in Classroom N with heating system set to be on with lower temperature. Although improving thermal properties of roof could also improve building performance in overall, the changes were not very significant. The main reason is that the case study has already had $5 \mathrm{~cm}$ thermal insulation in roof layers with $\mathrm{U}$ value of $0.5 \mathrm{w} / \mathrm{m}^{2} \mathrm{k}$. Improving the thermal properties of the roof could slightly enhance indoor air temperature that can be ignored as the current condition of roof with $\mathrm{U}$-value of $0.5 \mathrm{w} / \mathrm{m}^{2} \mathrm{k}$ is acceptable enough to keep the indoor air temperature in an acceptable range fluctuated from $23.5^{\circ} \mathrm{C}$ to $24.5{ }^{\circ} \mathrm{C}$.

Regarding thermal mass materials, although mediumweight and light-weight thermal mass materials such as concrete could increase indoor air temperature considerably, it is suggested to use heavy weight concrete or brick with $25 \mathrm{~cm}$ thickness to avoid overheating risks during warm season as heavy weight thermal mass can absorb heat during the day time in warm season, while releasing the heat slowly over night. The suggested thermal mass could keep the indoor air temperature within comfort bands that varied between $23^{\circ} \mathrm{C}$ and $24^{\circ} \mathrm{C}$ in north facing classroom and between $21^{\circ} \mathrm{C}$ and $24^{\circ} \mathrm{C}$ in south facing classroom in winter season.

Based on simulation analysis, which were discussed in Section 6, and the recommended strategies, the optimum design solutions were identified that could improve indoor thermal condition with the lowest heating energy use. The strategies include south and south-east orientation and thermal insulation material for outer side of external walls with $\mathrm{U}$-value between 0.28 and $0.32 \mathrm{w} / \mathrm{m}^{2} \mathrm{k}$, as well as thermal insulation material for inner side of the roof with $5 \mathrm{~cm}$ thickness and U-value of $0.5 \mathrm{~W} / \mathrm{m}^{2} \mathrm{~K}$. It is also recommended to use $25 \mathrm{~cm}$ high density concrete blocks as a thermal mass material for building envelope as well as double glazed windows (Optimum Solution 1). It should be noted that $30 \mathrm{~cm}$ outer brick is also an acceptable thermal mass material, which was considered as an alternative option (Optimum Solution 2). To predict the optimum design solutions, the heating system was set to be off to assess indoor thermal condition with the minimum energy use.

Figure 9 illustrates indoor air temperature in Classroom $\mathrm{N}$ and $\mathrm{S}$ using base case condition in comparison to the indoor air temperature using optimum design solutions. Although the indoor air temperature in Classroom S decreased around $3^{\circ} \mathrm{C}$ by the applications of optimum design solutions and with no heating system in operation in comparison to the base case with heating system set to be 

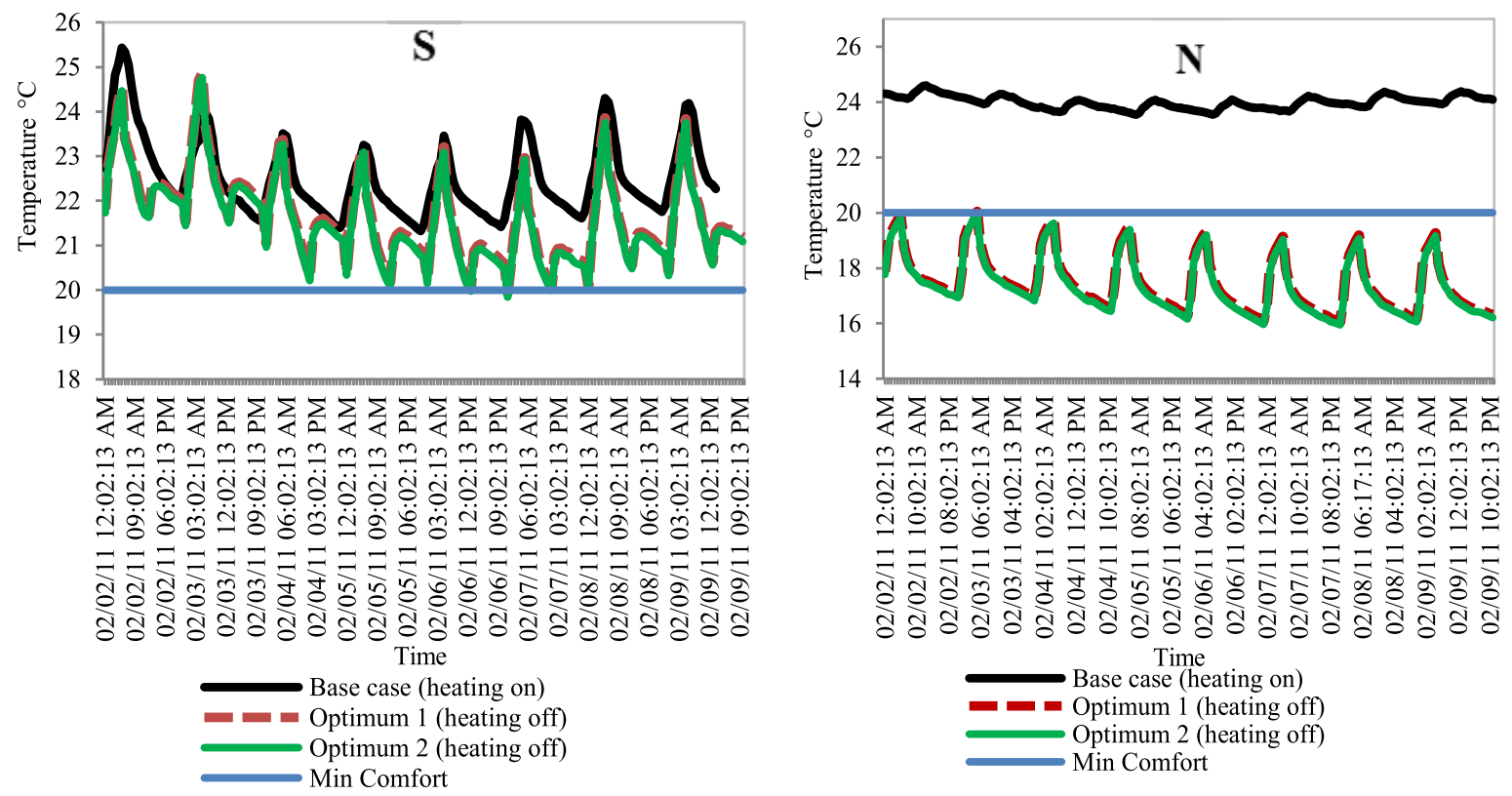

Fig. 9. Impact of optimum design solutions on indoor air temperature in Classrooms $\mathrm{S}$ and $\mathrm{N}$.

Table 7. Proposed passive design strategies for the female secondary school building in Tehran.

\begin{tabular}{lll}
\hline Passive design strategies & Solution & Current practice in a base case \\
\hline Orientation & $\begin{array}{l}\text { South-South East } \\
\text { Double glazed window with air in between } \\
\text { panes }\end{array}$ & $\begin{array}{l}\text { South } \\
6 \mathrm{~mm} \text { Single glazed }\end{array}$ \\
$\begin{array}{l}10 \mathrm{~cm} \text { common thermal insulation material } \\
\text { on outer side of external walls with u-value } \\
\text { between } 0.28 \text { and } 0.32 \mathrm{w} / \mathrm{m}^{2} \mathrm{k}\end{array}$ & No wall insulation \\
& $\begin{array}{l}5 \mathrm{~cm} \text { common thermal insulation materials } \\
\text { on inner side of roof with u-value } \\
\text { of } 0.5 \mathrm{w} / \mathrm{m}^{2} \mathrm{k}\end{array}$ & $\begin{array}{l}5 \mathrm{~cm} \text { insulation on outer side } \\
\text { of roof layers }\end{array}$ \\
Roof Insulation & $\begin{array}{l}25 \mathrm{~cm} \text { high-density concrete blocks or } 30 \mathrm{~cm} \\
\text { outer bricks in external walls }\end{array}$ & $30 \mathrm{~cm}$ brick in external walls \\
\hline
\end{tabular}

on, the indoor air temperature was still above minimum comfort band.

In addition, the reduction of indoor air temperature during the occupied period in Classroom $\mathrm{N}$ was more than Classroom S. The possible reason could be the orientation of the classroom. As the classroom faced north, the effect of thermal mass is much less than the south facing classroom because it obtains no solar radiation in winter period. However, the minimum indoor air temperature during the teaching hours is more than $17^{\circ} \mathrm{C}$ at all time, with no heating system in operation, which can be tolerated by wearing suitable clothes or using minimum heating energy. Table 7 shows the suggested optimum design solutions using passive design strategies for female secondary school building for the city of Tehran.

In overall, the optimum design solutions help to reduce energy consumption of the building considerably, while keeping indoor air temperature in an acceptable condition in winter season using passive design strategies and with respect to female students' thermal comfort. Therefore, in order to provide a high quality indoor environment and to increase learning performance of students, it is suggested to use the appropriate passive design strategies, which also reduce the need for supplementary heating in cold season and therefore save energy. However, the impact of suggested strategies on indoor thermal condition during warm season should be considered to avoid overheating risk.

Acknowledgements. The authors would like to state that this research work was completed as a part of a $\mathrm{PhD}$ study at the University of Sheffield.

\section{References}

1. V. Mikler, A. Bicol, B. Breisness, M. Labrie, Passive Design Toolkit, Vancouver, City of Vancouver, 2009 
2. Passive Design Toolkits for Homes, Vancouver, City of Vancouver, 2009

3. J. O'Connor, E. Lee, F. Rubinstein, S. Selkowitz, Tips for daylighting. The California Institute for Energy Efficiency (CIEE), The U.S. Department of Energy, Berkeley, CA, 1997

4. R. Jaques, H. Mardon, Passive design strategies, BUILD, 108, 84-85 (2008)

5. W.A.M. Sheta, Keeping Cool in Cairo: Thermal Simulation of Passive Cooling in Dwellings, PhD thesis, The University of Sheffield, 2012

6. R. Bruno, P. Bevilacqua, T. Cuconati, N. Arcuri, Energy evaluations of an innovative multi-storey wooden near Zero Energy Building designed for Mediterranean areas, Appl. Energy 238, 929-941 (2019)

7. P. Bevilacqua, F. Benevento, R. Bruno, N. Arcuri, Are Trombe walls suitable passive systems for the reduction of the yearly building energy requirements? Energy 185, 554-566 (2019)

8. R. Yao, V. Costanzo, X. Li, Q. Zhang, B. Li, The effect of passive measures on thermal comfort and energy conservation. A case study of the hot summer and cold winter climate in the Yangtze River region, J. Build. Eng. 15, 298-310 (2018)

9. I. Sarbu, C. Pacurar, Experimental and numerical research to assess indoor environment quality and schoolwork performance in university classrooms, Build. Environ. 93, 141-154 (2015)

10. M. Trebilcock, B. Piderit, J. Soto, R. Figueroa, A parametric analysis of simple passive strategies for improving thermal performance of school classrooms in Chile, Archit. Sci. Rev. 59, 385-399 (2016)

11. S. Subhashini, K. Thirumaran, A passive design solution to enhance thermal comfort in an educational building in the warm humid climatic zone of Madurai, J. Build. Eng. 18, 395-407 (2018)

12. F. Nicol, M.A. Humphrey, Adaptive thermal comfort and sustainable thermal standards for buildings. Windsor Conference 2001, Moving Thermal Comfort Standards into the 21st Century. Windsor: Network for Comfort and Energy Use in Buildings, 2001

13. F. Nasrollahi, Climate and Energy Responsive Housing in Continental Climates: The Suitability of Passive Houses for Iran's Dry and Cold Climate, Berlin, Berlin University of Technology, 2009

14. CABE, Creating excellent primary schools Commission for Architecture and the Built Environment London 2010

15. S. Heidari, Coping with Nature: Ten Years Thermal Comfort Studies in Iran. Adapting to Change: New Thinking on Comfort. Network for Comfort and Energy Use in Buildings, Windsor, UK, 2010

16. Pricewaterhousecoopers \& DCSF, Evaluation of Building Schools for the Future, Technical Report. London. 2007

17. H. Richardson, School buildings scheme scrapped. BBC News. http://www.bbc.co.uk/news/10514113 [Accessed 18 February 2013], 2010

18. DFE, Overhaul to England's school building programme. Department for Education. http://www.education.gov.uk/ inthenews/inthenews/a0061486/overhaul-build-prog [Accessed 15 February 2013], 2010
19. S. Iravani, The causes of inadequate development in educational status and school design in Iran in recent century. Tehran: DesignShare, P. Tec. http://www.design share.com/images/article2irvani.pdf [Accessed 13 October 2019], 2010

20. A. Ghaffari, Architectural design principles of educational spaces Tehran: State Organisation of Schools Renovation, development and mobilisation, 1998

21. Y. Gorji-Mahlabani, Climatic effects on school buildings. PhD thesis, The University of Sheffield, 2002

22. CBI, Annual Report. Tehran 2011

23. B. Ghazizadeh, Design principles of educational buildings Tehran: Nosazi Madares, 1993

24. M. Kasmai, Climate and Architecture, Nashr khak, Isfahan, 2008

25. Local Weather Data Iran Meteorological Organisation Tehran 2011; http://www.irimo.ir/

26. V. Limbachiya, K. Vadodaria, D. Loveday, V. Haines, Identifying a suitable method for studying thermal comfort in people's homes, in: The changing context of comfort in an unpredictable world, Windsor, 2012

27. Building Simulation DesignBuilder Software Ltd 2013; http://www.designbuilder.co.uk/

28. A. Mahdizadeh, Report on Retrofit Procedure of School Buildings in Islamic Republic of Iran. Ministry of Education State Organization of Schools Renovation, Tehran, 2011

29. M. Nosazi, Increase of study area per head in Iranian Schools, Tehran: State Organization of School Renovation, Development and mobilization. Available at http://www.nosazima dares.ir/News/_layouts/viewlsts.aspx [Accessed 7th Sep 2019], 2013

30. P.O. Fanger, Assessment of man's thermal comfort in practice, Br. J. Ind. Med. 30, 313-324 (1973)

31. M. Santamouris, Advances in Building Energy Research, Earthscan, London, 2008

32. ASHRAE, ASHRAE Standard 55. Thermal environmental conditions for human occupancy American Society of Heating, Refrigerating and Air-Conditioning Engineers Atlanta, GA 2004;

33. D.A. Mcintyre, R.R. Gonzalez, Man's thermal sensitivity during temperature changes at two levels of clothing insulation and activity, ASHRAE Trans. 82, 219-233 (1976)

34. Weather Data Sources, U.S. Department of Energy 2013; http://apps1.eere.energy.gov/buildings/energyplus/weath erdata sources.cfm

35. F. Su, J. Huang, T. Xu, C. Zhang, An evaluation of the effects of various parameter weights on typical meteorological years used for building energy simulation, Build. Simul. 2, 19-28 (2009)

36. D.B. Crawley, Which Weather Data Should You Use for Energy Simulations of Commercial Buildings? ASHRAE Trans. 104, 498-515 (1998)

37. Edit / translate hourly weather data DesignBuilder 2013; http://www.designbuilder.co.uk/helpv2/Content/_Edit_ hourly weather data.htm

38. S. Melki, M. Hayek, Building Simulation Tools and Their Role in Improving Existing Building Designs. ACTEA, Zouk Mosbeh, Labanon, 2009

39. Weather Data, U.S. Department of Energy 2013; http:// apps1.eere.energy.gov/buildings/energyplus/weatherdata_ about.cfm

40. B. Givoni, Climate considerations in building and urban design, Van Nostrand Reinhold, New York, 1998 
41. B. Ford, R. Schiano-Phan, D. Zhongcheng, The Passivhaus Standard in European Warm Climate: Design Guidelines for Comfortable Low Energy Homes- Part 3. Comfort, Climate and Passive Strategies. The University of Nottingham, Nottingham, 2007

42. AUTODESK ECOTECT ANALYSIS, Passive Design Natural Frequency. 2013; https://www.designingbuildings. co.uk/wiki/Passive_building_design

43. Thermal insulation of buildings Tehran Iranian fuel Conservation Company. 2012; http://ifco.ir/building/build/isula tion_extra1.asp

44. Thermal insulation types Iran's Insulation Encyclopedia Isfahan 2012; http://www.irima.ir/home/thermal-insula tion/thermal-insulation-classify

45. National Building Regulations of Iran Energy Saving Office of National Building Regulations Tehran 2009

46. E. Kruger, B. Givoni, Thermal monitoring and indoor thermal predictions in a passive solar building in an arid environment, Build. Environ. 43, 1792-1804 (2008)
47. AUTODESK SUSTAINABILITY WORKSHOP, Building Design Autodesk Education Community. 2011; http:// sustainabilityworkshop.autodesk.com/buildings/thermalmass

48. S.J. Byrne, R.L. Ritschard, A Parametric Analysis of Thermal Mass in Residential Buildings. Thermal Performance of the Exterior Envelopes of Buildings III. Clearwater Beach, Fla., ASHRAE/DOE/BTECC, 1985

49. R.L. Fehr, Guide to Building Energy Efficient Homes, Kentucky, Department of Biosystems and Agricultural Engineering, University of Kentucky, 2009

50. J.P. Ries, T.A. Holm, A holistic approach to sustainability for the concrete community: lightweight concrete-two millennia of proven performance. ESCSI, Salt Lake City, Utah, 2004

51. M.G. Vangeem, T.A. Holm, J.P. Ries, Optimal Thermal Mass and R-Value in Concrete First International Conference on Concrete Sustainability, Tokyo, Japan: ICCS13, 2013

Cite this article as: S. Zahiri and H. Altan: Improving energy efficiency of school buildings during winter season using passive design strategies. Sust. Build. 5, 1 (2020). 